\title{
Comparison of two commercial kits and two extraction methods for fecal glucocorticoid analysis in ocelots (Leopardus pardalis) submitted to ACTH challenge ${ }^{1}$
}

\author{
Eduardo Antunes Dias ${ }^{2}$, Marcilio Nichi ${ }^{2}$ and Marcelo A.B.V. Guimarães ${ }^{2}$
}

\begin{abstract}
Dias E.A., Nichi M. \& Guimarães M.A.B.V. 2008. Comparison of two commercial kits and two extraction methods for fecal glucocorticoid analysis in ocelots (Leopardus pardalis) submitted to ACTH challenge. Pesquisa Veterinária Brasileira 28(7):329-334. Departamento de Reprodução Animal, Faculdade de Medicina Veterinária e Zootecnia, Universidade de São Paulo, Av. Prof. Dr. Orlando Marques de Paiva 87, Cidade Universitária, São Paulo, SP 05508-270, Brazil. E-mail: eantdias@ usp.br

The ocelot (Leopardus pardalis) is included in list of wild felid species protected by CITES and is part of conservation strategies that necessarily involve the use of assisted reproduction techniques, which requires practical and minimally invasive techniques of high reproducibility that permit the study of animal reproductive physiology. The objective of this study was to compare and validate two commercial assays: ImmuChem Double Antibody Corticosterone 125I RIA from ICN Biomedicals, Costa Mesa, CA, USA; and Coat-a-Count Cortisol ${ }^{125}$ I RIA from DPC, Los Angeles, CA, USA, for assessment of fecal glucocorticoid metabolites in ocelots submitted to ACTH (adrenocorticotropic hormone) challenge. Fecal samples were collected from five ocelots kept at the Brazilian Center of Neotropical Felines, Associação Mata Ciliar, São Paulo, Brazil, and one of the animals was chosen as a negative control. The experiment was conducted over a period of 9 days. On day 0 , a total dose of $100 \mathrm{IU}$ ACTH was administered intramuscularly. Immediately after collection the samples were stored at $20 \mathrm{C}$ in labeled plastic bags. The hormone metabolites were subsequently extracted and assayed using the two commercial kits. Previously it was performed a trial with the DPC kit to check the best extraction method for hormones metabolites. Data were analyzed with the SAS program for Windows V8 and reported as means \pm SEM. The Schwarzenberger extraction method was slightly better when compared with the Wasser extraction method $(103,334.56 \pm$ $19,010.37 \mathrm{ng} / \mathrm{g}$ of wet feces and $59,223.61 \pm 12,725.36 \mathrm{ng} / \mathrm{g}$ of wet feces respectively; $P=0,0657$ ). The ICN kit detected an increase in glucocorticoid metabolite concentrations in a more reliable manner. Metabolite concentrations ( $\mathrm{ng} / \mathrm{g}$ wet feces) on day 0 and day 1 were $66,956.28 \pm 36,786.93$ and 92,991.19 $\pm 28,555.63$ for the DPC kit, and 205,483.32 $\pm 83,811.32$ and $814,578.75 \pm 292,150.47$ for the ICN kit, respectively. The limit of detection for the ICN kit was $7.7 \mathrm{ng} / \mathrm{mL}$ for $100 \% \mathrm{~B} / \mathrm{Bo}(25 \mathrm{ng} / \mathrm{mL}$ for $88 \% \mathrm{~B} / \mathrm{Bo})$ and for the DPC kit it was $0.2 \mathrm{ug} / \mathrm{dL}$ for $90.95 \% \mathrm{~B} / \mathrm{Bo}(1 \mathrm{ug} / \mathrm{dL}$ for $81.27 \% \mathrm{~B} / \mathrm{Bo})$. In conclusion it was confirmed that the Schwarzenberger extraction method and the ICN kit are superior for extracting and measuring fecal glucocorticoid metabolites in ocelot fecal samples.
\end{abstract}

INDEX TERMS: Stress, Leopardus pardalis, ocelot, ACTH challenge, fecal glucocorticoid.

\footnotetext{
${ }^{1}$ Received on April 14, 2008.

Accepted for publication on June 4, 2008.

2 Departamento de Reprodução Animal, Faculdade de Medicina Veterinária e Zootecnia, Universidade de São Paulo, Av. Prof. Dr. Orlando Marques de Paiva 87, Cidade Universitária, São Paulo, SP 05508-270, Brazil. ${ }^{*}$ Corresponding author: Hormone Analysis Laboratory / Management of Nature Conservation (MNC), Mezyad Road, P.O. Box 64634, Jebel Hafeet District, Al Ain, United Arab Emirates. E-mail: eantdias@usp.br
}

RESUMO.- [Comparação do desempenho de dois conjuntos comerciais e de dois métodos de extração para a análise de glicocorticóides fecais em jaguatiricas (Leopardus pardalis) submetidas ao desafio com ACTH.] A jaguatirica (Leopardus pardalis) é uma das espécies de felídeos selvagens listadas no CITES e integrante de planos de conservação que necessariamente envolvem o emprego de técnicas de reprodução assisti- 
da. Para isso, é fundamental o desenvolvimento de técnicas práticas, de alta repetibilidade e pouco invasivas, que permitam o estudo da fisiologia reprodutiva animal. Objetivou-se neste experimento comparar e validar os ensaios realizados com os conjuntos comerciais ImmuChem Double Antibody Corticosterone ${ }^{125}$ I RIE da ICN Biomedicals, Costa Mesa, CA, USA e Coat-a-count Cortisol ${ }^{125}$ I RIE da DPC, Los Angeles, CA, USA, na mensuração dos metabólitos de glicocorticóides das fezes de jaguatiricas por meio do desafio com ACTH. Para este estudo foram utilizadas amostras fecais de cinco indivíduos que se encontravam no Centro Brasileiro de Felinos Neotropicais, Associação Mata Ciliar, Pedreira, SP, Brasil, sendo que um destes animais foi escolhido como controle negativo. $\mathrm{O}$ experimento foi conduzido em um período de nove dias. No dia 0 foi administrada uma dose total de 100 UI IM de ACTH (hormônio adrenocorticotrópico). Imediatamente após a colheita, as amostras de fezes foram conservadas a $-20^{\circ} \mathrm{C}$ em sacos plásticos identificados e posteriormente os metabólitos hormonais foram extraídos e mensurados utilizando-se os dois conjuntos comerciais. Previamente foi realizado com o conjunto comercial da DPC um teste para comparar dois métodos de extração. Os dados foram analisados utilizando o programa The SAS System for Windows V8. A média \pm erro padrão dos valores obtidos pela técnica de Schwarzenberger foi levemente superior à média dos valores obtidos pela técnica de Wasser (103.334,56 \pm $19.010,37 \mathrm{ng} / \mathrm{g}$ de fezes úmidas e $59.223,61 \pm$ $12.725,36 \mathrm{ng} / \mathrm{g}$ de fezes úmidas, respectivamente; $P=0.0657$ ). O conjunto comercial da ICN detectou com maior clareza o aumento das concentrações dos metabólitos de glicocorticóides. Os valores do dia 0 e do dia 1 para os conjuntos comerciais DPC e ICN foram respectivamente $66.956,28 \pm 36.786,93 \mathrm{ng} / \mathrm{g}$ de fezes úmidas e $92.991,19 \pm 28.555,63 \mathrm{ng} / \mathrm{g}$ de fezes úmidas; $205.483,32 \pm 83.811,32 \mathrm{ng} / \mathrm{g}$ de fezes úmidas e 814.578,75 $\pm 292.150,47 \mathrm{ng} / \mathrm{g}$ fezes úmidas. Para o conjunto comercial da ICN a sensibilidade foi de $7,7 \mathrm{ng} / \mathrm{mL}$ para $100 \% \mathrm{~B} /$ Bo (25 ng/mL para $88 \% \mathrm{~B} / \mathrm{Bo})$ e para o conjunto comercial da DPC foi de 0,2ug/dL para $90,95 \%$ B/Bo (1ug/dL para $81,27 \%$ B/Bo). Confirmou-se, portanto, que a melhor técnica de extração foi a descrita por Schwarzenberger e que o conjunto comercial da ICN Biomedicals teve um melhor desempenho para a quantificação de metabólitos de glicocorticóides em fezes de jaguatiricas.

TERMOS DE INDEXACAO: Estresse, Leopardus pardalis, jaguatirica, desafio com ACTH, glicocorticóides fecais.

\section{INTRODUCTION}

All felid species of the Leopardus genus are included in the Brazilian fauna's endangered species list (Lista Nacional das Espécies da Fauna Brasileira Ameaçadas de Extinção, 2005) produced by the Brazilian Institute of the Environment and Renewable Natural Resources (IBAMA), as well as in the Appendix I of the Conservation Internati- onal Trade in Endangered Species of Wild Flora and Fauna (CITES), mainly as a result of fragmentation and loss of their habitat. The ocelot (Fig.1) is a medium-size nondomestic solitary cat which is primarily nocturnal.

In 2001, the ocelot population held in captivity in Brazil comprised 354 individuals (Adania 2002). This author investigated 180 animals (96 males and 84 females), including $8 \%$ cubs (less than 2 years of age), $51 \%$ adults (2 to 12 years old), and $41 \%$ old animals (more than 12 years old). No origin was reported for most of these animals. Despite a large number of births, the $L$. pardalis population held in captivity in Brazil is declining, with a mean growth rate of the population over the last 10 years of only $3 \%$ and a death rate of $11 \%$ for cubs younger than 30 days. In order to minimize this trend, the International Union of Directors of Zoological Gardens (IUDZG) and the Conservation Breeding Specialist Group (CBSG) of the International Union for the Conservation of Nature and Natural Resources (IUCN) recommend the use of assisted reproduction techniques as a tool for species conservation (IUDZG/CBSG 1993).

The measurement of glucocorticoid metabolites in feces is a noninvasive technique for remote monitoring of the animal's physiology that may reflect an adrenal response to potentially stressful agents (Wasser et al. 2000, Wielebnowski et al. 2002). Studies on the hormone metabolism of the family Felidae have demonstrated that most steroid hormone metabolites of gonadal and adrenal origin are excreted in feces (Graham \& Brown 1996a, Terio et al. 1999, Schatz \& Palme 2001, Wielebnowski et al.

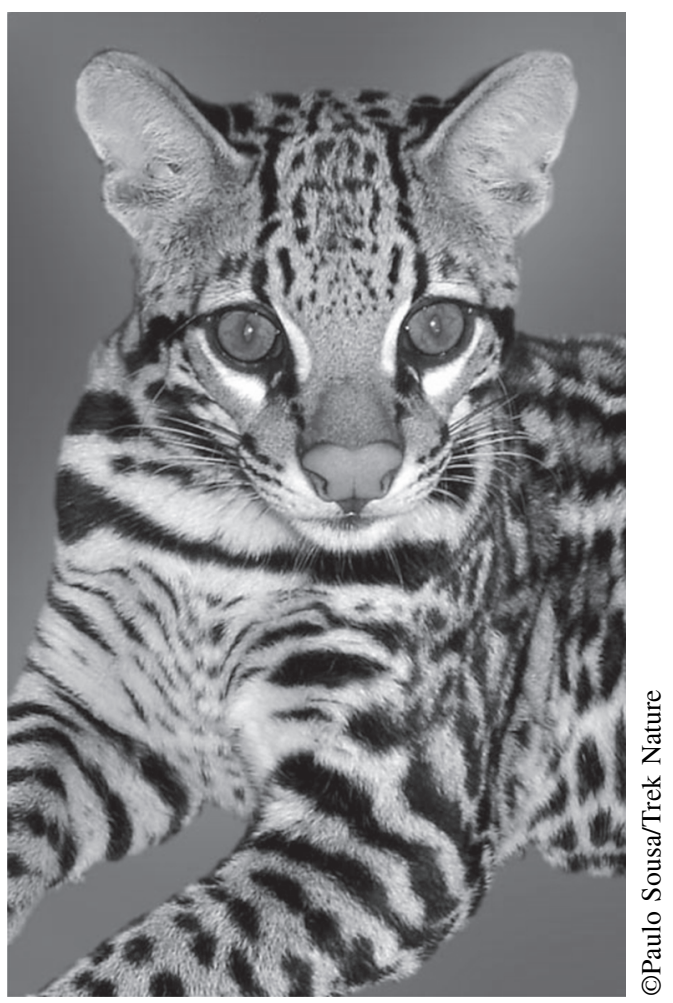

Fig.1. Ocelot (Leopardus pardalis) 
2002). The administration of adrenocorticotropic hormone (ACTH), or ACTH challenge, mimics a natural response of the adrenal gland to stress, causing a rapid increase in native glucocorticoids such as cortisol and corticosterone, followed by a return to basal levels within a few hours (Wasser et al. 2000).

The hormone metabolites extraction methods that are usually applied for fecal samples are described by Wasser et al. (1994) and Schwarzenberger et al. (1991). Briefly, the first method combine the supernatants from two extraction steps (boiling in ethanol solution before dissolving in methanol solution) and the second method use only one extraction step by dissolving in methanol solution.

Cortisol metabolites have been measured in feces using commercially available double-antibody corticosterone radioimmunoassay kits (Terio et al. 1999, Schatz \& Palme 2001) and in serum using the DPC solid-phase radioimmunoassay kit (Graham \& Brown 1996a, Terio et al. 1999). Several studies have concluded that the doubleantibody ${ }^{125}$ I RIA for corticosterone (ICN Biomedicals Inc., Costa Mesa, CA) shows a better performance in the detection of fecal glucocorticoid metabolites in different non-domestic species because of its high cross-reactivity with different metabolites (Graham \& Brown 1996a, Monfort et al. 1998, Terio et al. 1999; Wasser et al. 2000; Möstle \& Palme 2002, Wielebnowski et al. 2002) and that kit was also validated to quantify adrenal corticoid metabolites in felid feces (Graham \& Brown 1996, Wasser et al. 2000, Wielebnowski et al. 2002, Young et al. 2004, Moreira et al. 2007).

The aim of this study was to compare and validate two extraction methods and two commercial kits for the measurement of hormone metabolites in feces of ocelots submitted to ACTH challenge.

\section{MATERIALS AND METHODS}

Animals and handling (Enclosures and experimental design). For extraction of fecal glucocorticoid metabolites, feces were collected from adult male $(n=2)$ and female ocelots $(n=3)$ mated at the Brazilian Center of Neotropical Felids, Associação Mata Ciliar (AMC), Jundiaí (2310'38.14”S, 4656'29.81'W, $723 \mathrm{~m}$ height), São Paulo, Brazil. The estimated age for the Male 1 was 5 years old and for the Male 2 it was at least 12 years old. The estimated age for the Female 1 was 8 years old, for the Female 2 it was at least 12 years old and for the Female 3 it was 4 years old. Both project and Institution were certified by IBAMA. Diet consisted of dead rats (3-4 times per week), chicken necks (3 times per week), bovine heart (at least once a week to every 15 days), vitamin and mineral supplement ${ }^{3}$, and water ad libitum. Enclosures measured $3000 \mathrm{~mm} \times 7000 \mathrm{~mm} \times 2500 \mathrm{~mm}$, were covered with slab stone and were limited by netting in the frontal portion. The floor corresponding to the slab stone cover consisted of cement and the enclosure's open area was well insolated and contained logs, underbrush and shrub. The shift consisted of cement and contained a water trough and a wooden box with grass.

\footnotetext{
${ }^{3}$ Aminomix® Pet, Vetnil, Campinas, São Paulo, Brazil.
}

Hormone treatment and fecal sample collection. Ocelot couples were separated and one individual of each pair was housed in the shift during the experiment to facilitate sample collection. Each animal received food with adye (Coralim Mix ${ }^{\circ}$ ) of different color to make possible differentiation of the individual feces. The experiment was conducted over a period of nine days. Day 0 was defined as the boundary between the period without treatment (day -4 to day -1 ) and the period within treatment (day 1 to day 4). On day 0 , a total dose of $100 \mathrm{IU}$ tetracosactide ${ }^{4}$, a synthetic ACTH analog, was administered in the morning, with the animal being confined in a restraining cage. After this procedure, the animal was returned to its enclosure. Male 1 was chosen as negative control to determine the stress caused by confinement. It did not receive injection of tetracosactide but was stimulated by needle puncture. Immediately after collection of the total fecal bolus, the samples were labeled and stored in plastic bags at $-20^{\circ} \mathrm{C}$. This procedure was performed once a day throughout the 9 days period. It should be noted that not all animals defecated daily. Subsequently, the hormone metabolites were extracted at the Laboratory of Hormone Quantification (LDH), Department of Animal Reproduction from the Faculty of Medicine Veterinary (FMVZ), São Paulo University (USP), according to the technique of Schwarzenberger et al. (1991) concerning the efficacy of that protocol (Dias 2006).

Comparison of extraction methods. Before the ACTH challenge, it was performed a trial with the DPC-RIA kit with fecal samples from Female $2(n=9)$ to compare the extraction methods described by Shwarzenberger et al. and Wasser et al. For Schwarzenberger method the final volume used for the assay was $5 \mathrm{~mL}$ and for Wasser method final volume was $1 \mathrm{~mL}$. In brief, for the Wasser protocol it was used $0.2 \mathrm{~g}$ of well-mixed wet feces boiled in $5 \mathrm{ml}$ aqueous ethanol (90\%) for $25 \mathrm{~min}$. After centrifuging at $500 \mathrm{~g}$ for $15 \mathrm{~min}$, the supernatant was recovered and the pellet resuspended in $5 \mathrm{ml}$ aqueous ethanol $(90 \%)$, vortexed for $1 \mathrm{~min}$ and recentrifuged. Both ethanol supernatants were combined dried completely, redissolved in $1 \mathrm{ml}$ methanol and diluted in phosphate-buffered saline (0.01M PO4, $0.14 \mathrm{M} \mathrm{NaCl}, 0.5 \% \mathrm{BSA}$, $0.01 \% \mathrm{NaN} 3, \mathrm{pH} 7.0$ ) before analysis. For the Schwarzenberger method $5 \mathrm{ml}$ of aqueous methanol $(80 \%)$ was added to $0.5 \mathrm{~g}$ of well-mixed wet feces, vortexed for $1 \mathrm{~min}$ and homogenized over night. After centrifuging at $270 \mathrm{~g}$ for $15 \mathrm{~min}$, the supernatant was recovered and stored at $-20^{\circ} \mathrm{C}$.

Comparison of commercial kits. Fecal metabolites were measured by radioimmunoassay (RIA) comparing the ImmuChem Double Antibody Corticosterone ${ }^{125}$ I RIA kit from ICN Biomedicals and the Coat-a-Count Cortisol ${ }^{125}$ I RIA kit from DPC. Fecal hormone concentrations are expressed on a per gram wet fecal weight basis. The samples were diluted 1:4 for the DPC kit and 1:100 for the ICN kit. The two commercial kits were compared by analyzing the relative hormone profile after 9 days of the experiment, with special attention to the values obtained after the ACTH challenge (day 1). The limit of detection for the ICN kit was $7.7 \mathrm{ng} / \mathrm{mL}$ for $100 \%$ B/Bo $(25 \mathrm{ng} / \mathrm{mL}$ for $88 \%$ $\mathrm{B} / \mathrm{Bo}$ ) and for the DPC kit it was $0.2 \mathrm{ug} / \mathrm{dL}$ for $90.95 \% \mathrm{~B} / \mathrm{Bo}$ (1 $\mathrm{ug} / \mathrm{dL}$ for $81.27 \% \mathrm{~B} / \mathrm{Bo}$ ). The parallelism test was performed only for the ICN kit assay validation since the DPC kit has been validated and is routinely used for laboratory hormone analysis. A total of 44 samples were collected and processed (approx. 9

\footnotetext{
${ }^{4}$ Synacthen Depotâ, Novartis, Paris, France; human use, $800 \mathrm{IU} / \mathrm{mg}$, $1 \mathrm{mg} / \mathrm{mL}$.
} 
samples from each animal). It should be noted that only one sample from Female 1 was missing (day -4).

Statistical analysis. All data were statistically evaluated using the SAS System for Windows (SAS Institute Inc., Cary, NC, USA, 2000). Differences between treatments throughout the experimental period were analyzed using the PROC MIXED procedure. Whenever necessary, the data were transformed in order to obey these statistical assumptions, which was the case for the validation of the ICN kit (1.5 exponential). A $P$ value $<0.05$ was considered to be statistically significant. Pearson and Spearman correlations were used to calculate the relationship between kits and hormone measurements for parametric and nonparametric variables. Values are presented as mean \pm SEM.

\section{RESULTS}

The comparison between the two extraction methods is shown in Figure 2. The correlation coefficient between both methods was $0.90(P<0.0001)$ and the regression coefficient between the extractions was $0.80(P<0.0001)$. The mean overall (SEM) for the Wasser method was $59,223.61 \pm 12,725.3 \mathrm{ng} / \mathrm{g}$ wet feces with $79 \%$ of recovery

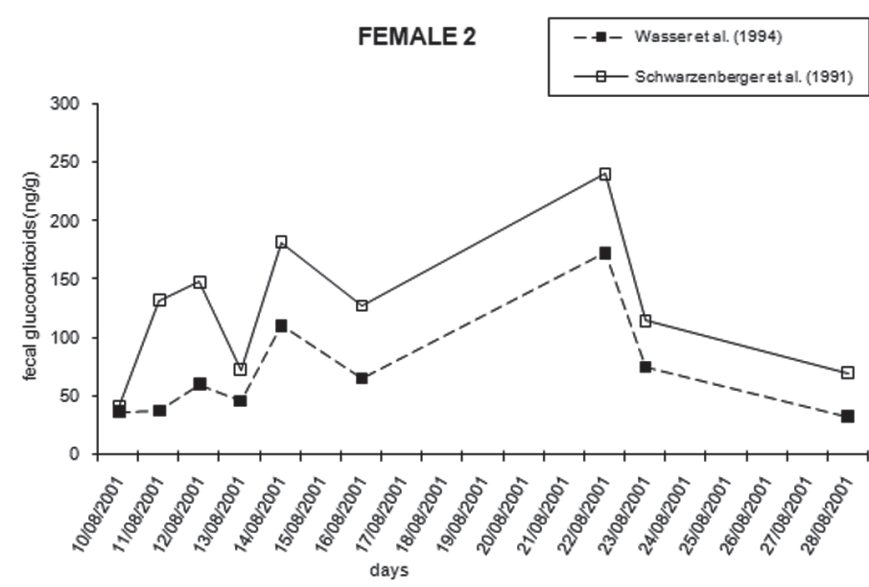

Fig.2. Glucocorticoids profile from ocelots (Leopardus pardalis) fecal samples extracted by Wasser and Schwarzenberger methods using DPC-RIA kit. and for the Schwarzenberger method the arithmetic mean overall (SEM) was 103,334.56 $\pm 19,010.37 \mathrm{ng} / \mathrm{g}$ wet feces with $73 \%$ of recovery.

For the comparison between the two commercial kits the average concentration of metabolites ( $\mathrm{ng} / \mathrm{g}$ feces) was $226,226.4 \pm 18,004$ for the samples analyzed by the ICNRIA kit ( $n=44)$ and 54,898.31 $\pm 10,333.81$ for the samples analyzed by DPC-RIA kit $(n=44)$. The average metabolite concentrations for all samples that fell below the overall mean +2.0 standard deviations (SD) was 152,762.1 \pm $23,848.04$ for the ICN-RIA kit $(n=31)$ and 41,277.19 \pm $4,324.211$ for the DPC-RIA kit $(n=7)$. The average metabolite concentration for all samples greater than the overall mean +2.0 SD was 920,697.7 $\pm 232,243.8(n=4)$ for the ICN-RIA kit and 111,526.3 for the DPC-RIA kit $(n=1)$.

With respect to the intra-assay controls, for the ICN kit the coefficient of variation (CV) for the low control was $1.18 \%$, whereas the CV for the high control was $10.53 \%$. In contrast, for the DPC kit the CV for the low control was $7.59 \%$, whereas the CV for the high control was $2.81 \%$. No inter-assay controls were performed.

For the parallelism test using the ICN commercial kit the regression analysis provided a coefficient of 0.99 $(P=0.0006)$. Comparison between the two commercial kits revealed a correlation of $0.90(P<0.0001)$.

The mean, standard error of the mean and level of significance of fecal glucocorticoid metabolite concentrations in the ocelots Male 2, Female 1, Female 2 and Female 3 submitted to an ACTH challenge are shown in Table 1. Fecal glucocorticoid metabolite levels on day 0 and day 1 were 66,956.28 \pm 36,786.93 and 92,991.19 \pm $28,555.63 \mathrm{ng} / \mathrm{g}$ wet feces as measured with the DPC kit, and $205,483.32 \pm 83,811.32$ and $814,578.75 \pm$ $292,150.47 \mathrm{ng} / \mathrm{g}$ wet feces as measured with the ICN kit, respectively. No significant difference between metabolite levels measured with the two kits was observed on day 0 $(P<0.1326)$ but there was a significant difference on day 1 $(P<0.0282)$. Figure 2 illustrates the superior performance of the ICN kit compared to the DPC kit.

Table 1. Means ( \pm SEM) comparisons between fecal glucocorticoid levels measured with the ICN and DPC radioimmunoassay kits in ocelots (one male and three females) (Leopardus pardalis) submitted to an ACTH challenge

\begin{tabular}{cccc}
\hline $\begin{array}{c}\text { Day of } \\
\text { treatment }\end{array}$ & DPC & ICN & $P$ \\
\hline-4 & $30,733.49 \pm 22,237.96 \mathrm{ab}$ & $101,135.0332,551.14^{\mathrm{a}}$ & 0.2619 \\
-3 & $37,692.65 \pm 19,334.77^{\mathrm{ab}}$ & $131,722.8127,723.10^{\mathrm{a}}$ & 0.0605 \\
-2 & $36,040.90 \pm 1,366.02 \mathrm{ab}$ & $152,669.85 \pm 20,736.52^{\mathrm{a}}$ & $0.0006^{*}$ \\
-1 & $34,058.60 \pm 7,900.24 \mathrm{ab}$ & $182,410.6042,179.31^{\mathrm{a}}$ & $0.0054^{*}$ \\
0 & $66,956.28 \pm 36,786.93 \mathrm{ab}$ & $205,483.3283,811.32^{\mathrm{a}}$ & 0.1326 \\
1 & $92,991.19 \pm 28,555.63 \mathrm{a}$ & $814,578.75 \pm 292,150.47^{\mathrm{b}}$ & $0.0282^{*}$ \\
2 & $37,238.49 \pm 11,575.09 \mathrm{ab}$ & $192,477.1332,889.12^{\mathrm{a}}$ & $0.0097^{*}$ \\
3 & $53,951.84 \pm 9,368.86 \mathrm{ab}$ & $166,040.67 \pm 57,703.45^{\mathrm{a}}$ & 0.1164 \\
4 & $27,140.66 \pm 5,899.59$ ab & $160,545.2250,493.24^{\mathrm{a}}$ & $0.0123^{*}$
\end{tabular}

a,b,ab: Different letters indicate significant differences between treatment days $(P<0.05)$; * indicates significant difference between the DPC and ICN kits on a given day of treatment $(P<0.05)$. 
Table 2. Mean overall (SEM), baseline (SEM), and peak concentration of fecal glucocorticoids for individuals examined by longitudinal glucocorticoids evaluation

\begin{tabular}{|c|c|c|c|c|}
\hline Individual & $\begin{array}{l}\text { Samples } \\
\text { (n) }\end{array}$ & $\begin{array}{l}\text { Mean Overall } \\
\text { (ng/g wet feces) }\end{array}$ & $\begin{array}{l}\text { Mean Baseline } \\
\text { (ng/g wet feces) }\end{array}$ & $\begin{array}{c}\text { Peak } \\
\text { (ng/g wet feces) }\end{array}$ \\
\hline Male 1 & 9 & $168,639 \pm 18,275.2$ (ICN kit) & - & - \\
\hline $\begin{array}{l}\text { (negative } \\
\text { control) }\end{array}$ & & $13,548 \pm 4,197.4$ (DPC kit) & - & - \\
\hline Male 2 & 9 & $\begin{array}{l}281,313.709 \pm 123,670.117 \text { (ICN kit) } \\
66,144.3069 \pm 13,999.7522 \text { (DPC kit) }\end{array}$ & $160,841 \pm 31,679$ (ICN kit) & $\begin{array}{c}1,245098.04(\text { ICN kit) } \\
\text { - }\end{array}$ \\
\hline Female 1 & 8 & $\begin{array}{c}302,596.5 \pm 93,078.51 \text { (ICN kit) } \\
50,058.33 \pm 9,546.337 \text { (DPC kit) }\end{array}$ & $\begin{array}{l}211,333.4 \pm 21,123.55 \text { (ICN kit) } \\
41,277.19 \pm 4,324.211 \text { (DPC kit) }\end{array}$ & $\begin{array}{c}941,438.3 \text { (ICN kit) } \\
111,526.32 \text { (DPC kit) }\end{array}$ \\
\hline Female 2 & 9 & $\begin{array}{l}242,764 \pm 127,616 \text { (ICN kit) } \\
124,993 \pm 20,504.5 \text { (DPC kit) }\end{array}$ & $118,228 \pm 31,600$ (ICN kit) & 1,239054.6 (ICN kit) \\
\hline Female 3 & 9 & $\begin{array}{c}135,819 \pm 18,004 \text { (ICN kit) } \\
19,747.9 \pm 3,421.17 \text { (DPC kit) }\end{array}$ & 120,646 $\pm 10,989.6$ (ICN kit) & 257,199.9 (ICN kit) \\
\hline
\end{tabular}

Table 2 shows the mean overall (SEM), baseline (SEM), and peak concentration of fecal glucocorticoid for all individuals examined by longitudinal glucocorticoid evaluation.

\section{DISCUSSION}

The results from the extraction methods confirms that the Schwarzenberger method had a better performance when compared with the Wasser method $(103,334.56 \pm$ $19,010.37 \mathrm{ng} / \mathrm{g}$ wet feces and $59,223.61 \pm 12,725.36 \mathrm{ng} / \mathrm{g}$ wet feces respectively) even when the recovery rate was similar $(73 \%$ and $79 \%$ respectively; correlation coefficient of $0.90, P<0.0001)$. Further the Schwarzenberger method

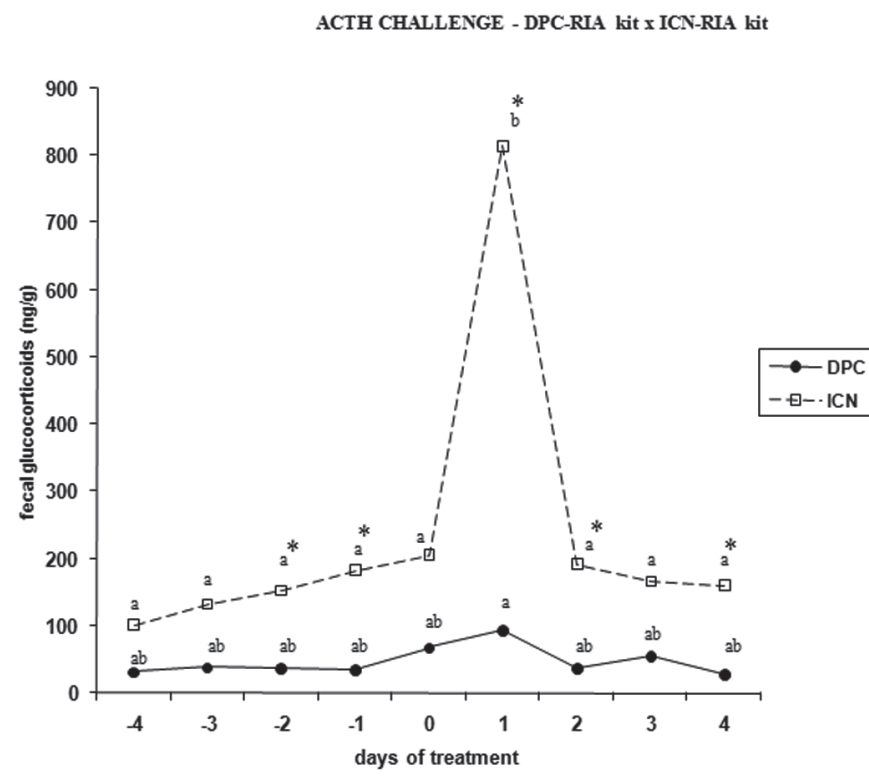

A,b,ab: Different letters indicate significant differences between treatment days $(P<0.05)$; ${ }^{*}$ indicates significant difference between the DPC and ICN kits on a given day of treatment $(P<0.05)$.

Fig.3. Longitudinal profiles of fecal glucocorticoids measured by ICN (dashed lines and empty squares) and DPC (filled circles) commercial kits, in adult ocelots $(n=4)$ (Leopardus pardalis) housed in couples at the Mata Ciliar Association. Hormone metabolites were extracted according to the modified technique of Schwarzenberger et al. (1991). is easier to perform because of fewer equipments and time required.

The ICN kit more reliably detected an increase in glucocorticoid metabolite concentrations after the ACTH challenge. Analysis of Figure 3 shows that this commercial kit reflects the biological event by presenting a more marked profile of variation in glucocorticoid metabolite levels. An increase in glucocorticoid metabolite concentrations was observed in all animals on the day after the challenge, as also demonstrated by Graham \& Brown (1996b). The profile obtained for the control animal (Male 1) did not show a peak on day 1 or day 2, suggesting that physical restraint in a restraining cage and intramuscular penetration of the needle did not interfere with the increase in glucocorticoid metabolite concentrations (Fig.4).

Using the ICN kit, fecal metabolite levels measured on day 1 (814,578.75 $\pm 292,150.47 \mathrm{ng} / \mathrm{g}$ wet feces), indicated by the letter $b$ (Fig.3), differed from all other days, indicated by the letter a (mean of $161,616.26 \pm 43,244.39 \mathrm{ng} / \mathrm{g}$ wet feces), demonstrating that this commercial kit was able to statistically differentiate day 1 (peak day) from all other days, an interesting finding since basal levels were

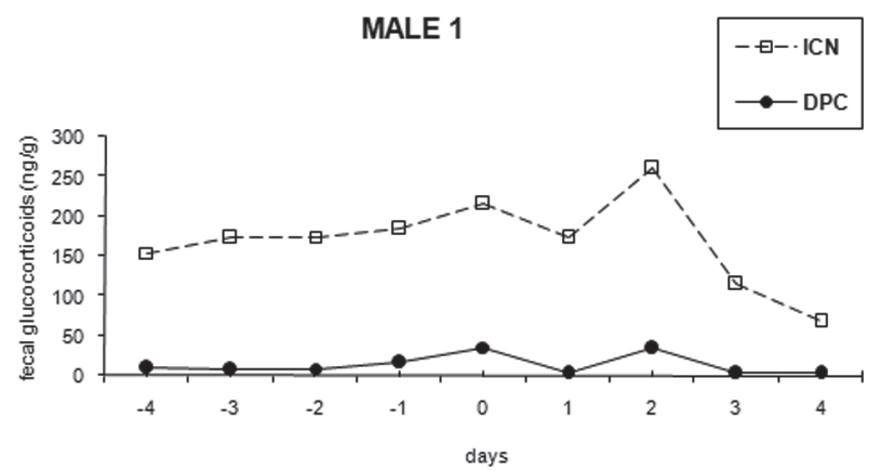

Fig.4. Longitudinal profiles of fecal glucocorticoids measured by ICN (dashed lines and empty squares) and DPC (filled circles) commercial kits, in an adult ocelot (Male 1) (Leopardus pardalis) housed at the Mata Ciliar Association and used as a negative control. Hormone metabolites were extracted according to the modified technique of Schwarzenberger et al. (1991). 
observed on the other days. Statistically differentiate of day $1(92,991.19 \pm 28,555.63 \mathrm{ng} / \mathrm{g}$ wet feces) and all other days also was found when using the DPC commercial kit, but in a lower level. The consequences of that lower capacity of glucocorticoids detection is shown in Table 2. The DPC kit was competent to detect a peak on glucocorticoids levels only for the Female 1.

These results are in accordance with Wasser et al. (2000) who demonstrated that measurement of fecal glucocorticoids using the ICN corticosterone antibody effectively detects changes in endogenous adrenal activity in a diverse spectrum of mammalian and avian species because of its cross-reactivity with multiple glucocorticoid metabolites excreted in feces, in contrast to other commercial kits. Möstle \& Palme (2002) also reported that the ICN corticosterone antibody yielded better results in the measurement of fecal glucocorticoids. The present study confirms the biological relevance of the ICN kit and physiologically validates this assay for the measurement of fecal glucocorticoid metabolites in ocelots.

\section{CONCLUSIONS}

The Schwarzenberger extraction method proved to have better performance when compared with the Wasser extraction method; and the ImmuChem Double Antibody Corticosterone ${ }^{125}$ I RIA from ICN Biomedicals was superior to the Coat-a-Count Cortisol ${ }^{125}$ I RIA from DPC for measuring fecal glucocorticoid metabolites in ocelots, and it was validated biologically. Thus, the use of that extracting method and commercial kit should be recommended for this purpose.

Acknowledgements.- The authors thank the Coordenação de Aperfeiçoamento de Pessoal de Nível Superior (CAPES/DS) for financial support, Dr. Cláudio Alvarenga de Oliveira and staff from the Laboratório de Dosagens Hormonais (LDH) of Faculdade de Medicina Veterinária e Zootecnia, USP, for the hormone analysis, and MSc. Cristina Harumi Adania and Daniel Barreto de Siqueira from Associação Mata Ciliar for making the animals available for the experiment.

\section{REFERENCES}

Adania C.H. 2002. Elaboração e análise de registro genealógico (studbook) de jaguatirica (Leopardus pardalis) em cativeiro no Brasil. MSc Dissertation, Universidade de São Paulo, São Paulo. 157p.
Dias E.A. 2006. Noninvasive assessment of adrenocortical activity by fecal glucocorticoids and progestins analysis in ocelots (Leopardus pardalis) submitted to ACTH challenge. PhD Thesis, Universidade de São Paulo, São Paulo. 72p.

Graham L.H. \& Brown J.L. 1996a. Cortisol metabolism in the domestic cat and implications for noninvasive monitoring of adrenocortical function in endangered felids. Zoo Biol. 15:71-82.

Graham L.H. \& Brown J.L. 1996b. Non-invasive assessment of gonadal and adrenocortical function in felid species via fecal steroid analysis. Proceedings 1st International Symposium of Physiology and Ethology of Wild and Zoo Animals, Berlin, p.18-21.

IUDZG/CBSG 1993. International Union of Directors of Zoological Gardens / Conservation Breeding Specialist Group. The world zoo conservation strategy: the role of the zoos and aquaria of the world in global conservation. Zoological Society, Chicago. 76p.

Lista nacional das espécies da fauna brasileira ameaçadas de extinção 2005. Electronic Publication. Instituto Brasileiro do Meio Ambiente e dos Recursos Naturais Renováveis (IBAMA), Ministério do Meio Ambiente (MMA). Available at: http://www.mma.gov.br/port/sbf/fauna/. Accessed July 12, 2005.

Moreira N., Brown J.L., Moraes W., Swanson W.F. \& Monteiro Filho E.L.A. 2007. Effect of housing and environmental enrichment on adrenocortical activity, behavior and reproductive cyclicity in the female tigrina (Leopardus tigrinus) and margay (Leopardus wiedii). Zoo Biology 26:441-460.

Möstle E. \& Palme R. 2002. Hormones as indicators of stress. Domest. Anim. Endocrinol. 23:67-74.

Schatz S. \& Palme R. 2001. Measurement of fecal cortisol metabolites in cats and dogs: A non-invasive method for evaluation adrenocortical function. Vet. Res. Commun. 25:271-287.

Schwarzenberger F., Möstle E., Bamberg E., Pammer J. \& Schmehlik O. 1991. Concentration of progestagens and oestragens in the faeces of a pregnant Lipizzan, trotter and Thoroughbred mares. J. Reprod. Fertil. 44(Suppl.):489-499.

Terio K.A., Citino S.B. \& Brown J.L. 1999. Fecal cortisol metabolite analysis for noninvasive monitoring of adrenocortical function in the cheetah (Acinonyx jubatus). J. Zoo Wildlife Med. 30:484-491.

Wasser S.K., Hunt K.E., Brown J.L., Cooper K., Crockett C.M., Bechert U., Millspaugh J.J., Larson S. \& Monfort S.L.A. 2000. Generalized fecal glucocorticoid assay for use in a diverse array of nondomestic mammalian and avian species. Gen. Comp. Endocrinol. 120:260-275.

Wasser S.K, Monfort, S.L., Southers J. \& Wildt D.E. 1994. Excretion rates and metabolites of oestradiol and progesterone in baboon (Papio cynocephalus cynocephalus) faeces. J. Reprod. Fertil. 101:213-220.

Wielebnowski N.C., Fletchall N., Carlstead K., Busso J.M. \& Brown J.L. 2002. Noninvasive assessment of adrenal activity associated with husbandry and behavioral factors in North American clouded leopard population. Zoo Biol. 21:77-98. 